\title{
Mining
}

\section{Performance of direct and reverse Samarco grinding circuits}

\section{Desempenho dos circuitos de moagem direto $e$ inverso da Samarco}

\author{
Andreia Carolina Rosa \\ Engenheira de processo \\ Gerência de tecnologia e ecoeficência \\ Samarco Mineração, Brazil \\ andreiar@samarco.com

\section{Homero Delboni Jr} \\ Professor Dr. \\ Departamento de Engenharia de \\ Minas e de Petróleo \\ Universidade de São Paulo, Brazil \\ hdelboni@usp.br
}

\begin{abstract}
This paper compares the performance associated with both direct and reverse ball mill closed circuit configurations. Survey campaigns were carried out in both Samarco Mineração industrial plants, i.e., Concentrator I and Concentrator II. The former is equipped with a reverse-configured ball mill closed grinding circuit, while the latter is equipped with ball mills under a direct closed circuit. The study consisted of laboratory jar tests, as well as comparisons between historical data obtained for both industrial plants. Comparisons based on historical data indicated that Concentrator II, configured in a direct mode, exhibited a better performance than that of Concentrator I. Such a conclusion is in contrast with the results obtained from survey campaigns, which indicated a better performance for the reverse configuration. Such a difference was determined by the performance of the classification stage, carried out in cyclones, as demonstrated by simulations conducted on the basis of previously calibrated models.
\end{abstract}

Keywords: iron ore, grinding, classification.

\section{Resumo}

Os aspectos operacionais entre as configurações de circuito fechado de moagem em moinhos de bolas, quais sejam, os circuitos direto e inverso, foram analisados comparativamente. Foram realizadas amostragens no circuito industrial de moagem primária do Concentrador I de Germano, operando sob ambas as configurações, além de serem analisados os dados históricos industriais dos Concentradores I e II. Por fim, foram realizados ensaios de moagem em laboratório, simulando ambas as condições. A comparação entre os históricos dos dados industriais dos Concentradores I (operando sob circuito inverso) e do Concentrador II (operando sob circuito direto) mostrou um histórico consistente em que o circuito do Concentrador II apresenta menor consumo energético por tonelada de material gerado abaixo da malha de controle do circuito. Esses resultados foram diferentes daqueles obtidos a partir das amostragens realizadas no circuito industrial da Samarco, os quais indicaram melhor desempenho do circuito inverso. A diferença foi atribuída à etapa de classificação, cujo desempenho determina a alteração ou até mesmo anula os benefícios, conforme demonstram os resultados de simulação posteriores.

Palauras chave: Minério de ferro, moagem, classificação. 


\section{Introduction}

The study of comminution processes is a significant part of ore processing history. One of the main reasons for this significance is the importance of these processes in beneficiation plants, either for the liberation of the minerals before concentration operations or to make products or sub-products that are adequate for the market or for downstream processes.

Additionally, comminution processes are, in general, responsible for a major percentage of operational costs, which justifies the many studies in the literature referring to the best choice, sizing, and optimization of comminution circuits.

Although many comminution technologies have been developed in the last few decades, typical comminution circuits still rely on the combination of crushers and screens or ball mills and cyclones. Hydrocyclones are largely employed due to their simplicity and large throughput.

There are two main configura-

\section{Methodology}

The comparative analysis between the direct and reverse configurations was based on four sources of data:

Sampling campaigns were conducted in two distinct situations:

- Periods when Concentrator I were operating under regular conditions (to obtain the data related to the reverse tions used for grinding circuits, namely reverse circuits and direct circuits. In the first case, the new feed of the circuit is reported to the classification stage, whose coarse fraction feeds the mill, while the fines are sent to the circuit product flow. In the direct circuit, the new feed reports directly to the mill before classification.

Both configurations have advantages and disadvantages, which have been extensively discussed by specialists. The reverse circuit prevents the passage of finished sizes inside the mill, reducing overgrinding. In contrast, the direct circuit offers more operational simplicity such as by eliminating the need to place the mineral particles in water suspension, which is a very critical operation, especially for dense materials.

However, despite all these discussions, there is very little information in literature regarding the comparison between direct and reverse circuits, and, most importantly, there is a limited amount of industrial data available to support these comparisons.

In this context, the grinding circuit of Concentrator I, in Germano, from Samarco Mineração, offers an important opportunity. This circuit has six mills, namely, two pre-primary mills and four primary mills, which correspond to the first and second stages of grinding, respectively. The pre-primary mills operate in open circuit and are fed with the crushed ore. The product of the pre-primary mills feeds two primary mills each, which operate in a closed, reverse circuit configuration. The designations routinely used in Samarco were kept. On the occasions when the pre-primary mills are shut down, the crushed ore is fed directly into the primary mills. Therefore, industrial data can be obtained from equipment operating in both circuit configurations. These data were used in this study to analyze both types of circuits.
- Sampling campaigns conducted in the industrial grinding circuit of Concentrator I

- Historical data from both

circuit)

- Periods when the pre-primary mills were shutdown (to obtain the data related to the direct circuit).

In both cases, the samples were col-

\section{Concentrator I and Concentrator II of Germano Mine \\ - Jar mill lab tests \\ - Computer simulations.}

lected at points corresponding to the new feed of the circuit, primary mill products, feed, underflow and overflow of the hydrocyclones. Figure 1 shows the grinding circuit of Concentrator I.

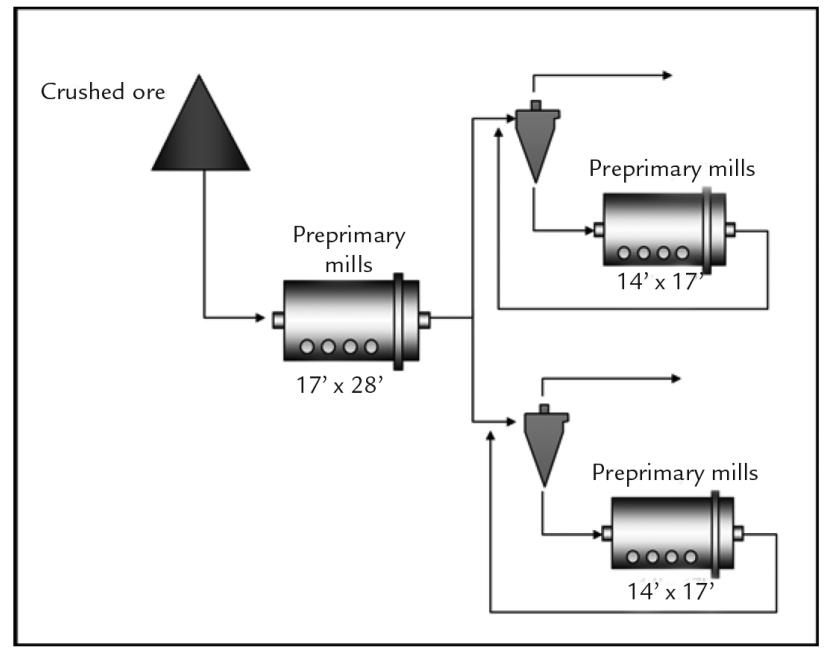

Slurry samples were collected over a one-hour period, with incremental samples taken each 10 minutes. Granulated materials were collected as a snapshot sample. During the sampling campaigns, industrial data were registered. For each sample, slurry density (or moisture content) and size analyses were conducted following standard procedures.
Figure 1

Pre-primary and primary grinding circuit of Germano Concentrator I.

From the operational data, it was possible to calculate the Operating Work Index and specific energy consumption per amount of material finer than the grind size $(\mathrm{kWh} / \mathrm{t}-100 \#)$, 
which were used for the comparison of both circuits.

For the operational work indexes,

The grinding tests followed the methodology proposed by Donda (2003), which is routinely used at Samarco for process control. This methodology consists of a series of grinding jar tests that are run in crescent periods of time under standardized conditions. The sample is ground until the desired product is achieved, as specified by industrial circuit specifications $(90 \%$ passing in 0.149 $\mathrm{mm})$. This methodology was calibrated to predict the specific energy consumption of the original industrial circuit of

\section{Results and discussion}

The Operating Work Indexes, calculated with the data obtained from the sampling campaigns, demonstrated that the specific energy consumption for the direct circuit was, on average, 30\% lower than that for the reverse circuit. However, it was considered important to apply certain correction factors to this parameter due to the differences observed between the F80 and the reduction ratios

Figure 2

Operating Work Indexes. the correcting factors proposed by Rowland (1983) were applied for the evaluation of industrial circuits. The use

$$
F e=\frac{F}{\left(\frac{2-(F c / F)^{1 / \sqrt{2}}}{2}\right)^{\sqrt{2}}}
$$

Concentrator I of Germano, which was originally designed as a direct closed circuit.

The grinding tests were conducted with a sample collected from the industrial circuit of Germano Concentrator II. This was called the "standard sample" and consists of an increment of the feed from the industrial circuit crushed below $9.5 \mathrm{~mm}$. In addition to these standardized conditions, an additional test was conducted using the standard sample fraction above $0.210 \mathrm{~mm}$. This

for both types of circuits. The reduction ratio during operation in reverse mode was smaller than that observed during operation in the direct mode. As shown by the typical characteristics of a grinding curve, the specific energy consumption usually increases as the feed size decreases (for the same product specifications). Bond (1961) also observed that the Work Index parameter is influenced by the grinding product of Bond's factor (1960) for the scalped feeds was also evaluated. This factor can be obtained by the following equation: additional test was performed to evaluate the benefits of the reverse circuit by removing the natural fines from the mill feed. The $0.210-\mathrm{mm}$ sieve was chosen to simulate the industrial circuit product characteristics.

Finally, computer simulations were used to evaluate the influence of the classification stage on the global grinding circuit. The model used was proposed by Nageswararao in 1978 (apud JKTech, 2009) and calibrated with industrial data from Germano Concentrator II. size and attributed those variations to the natural heterogeneities of the ore. Among the correction factors proposed by Rowland (1983) for the operating Wi is the EF7, which is associated with the reduction ratio of the circuit.

After applying the correction factors, the Operating Work Indexes for the direct circuit were $8 \%$ lower than those for the reverse circuit, as shown in Figure 2.
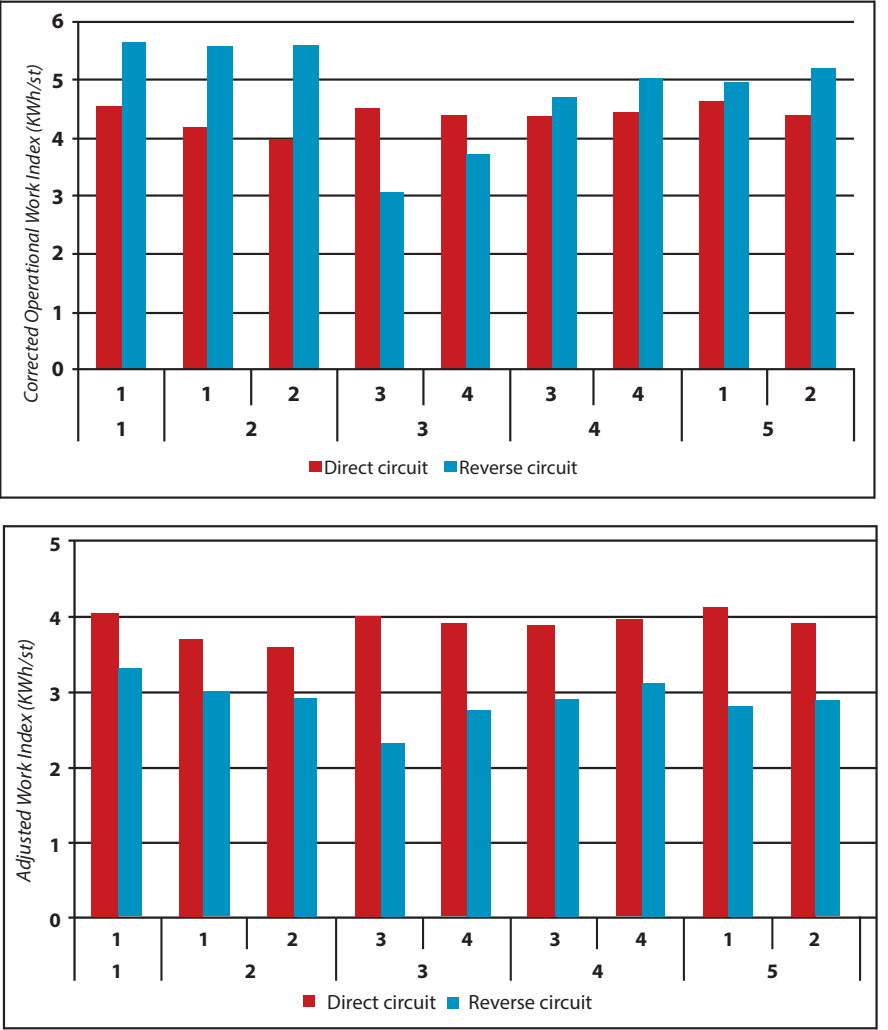
Figure 3 provides a comparison of industrial data between the two types of circuits after the application of the factor for scalped feeds to the data from the reverse circuit. It can be seen that the Operating Work Index was consistently smaller for the reverse circuit, which contradicts the results

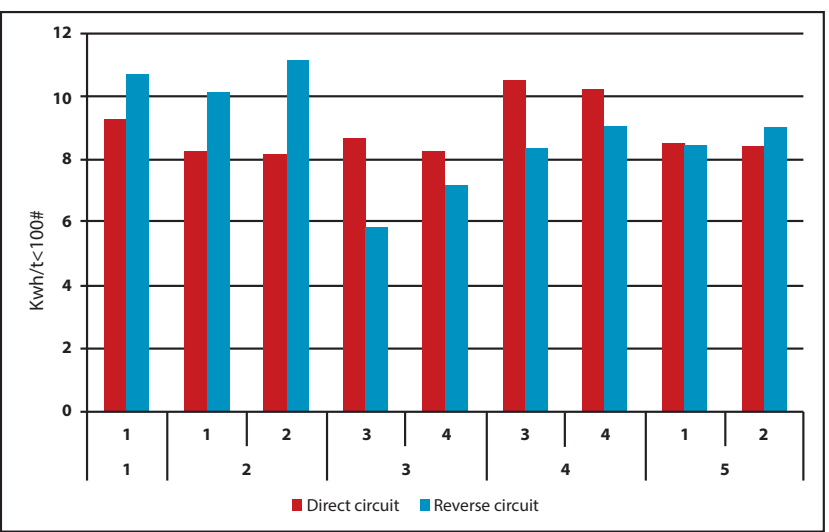

To confirm the results obtained from the sampling campaigns, historical data from both concentrators were compared, demonstrating that the primary grinding circuit of Germano Concentrator II (which operates in the direct configuration) exhibits a smaller specific energy consumption than the

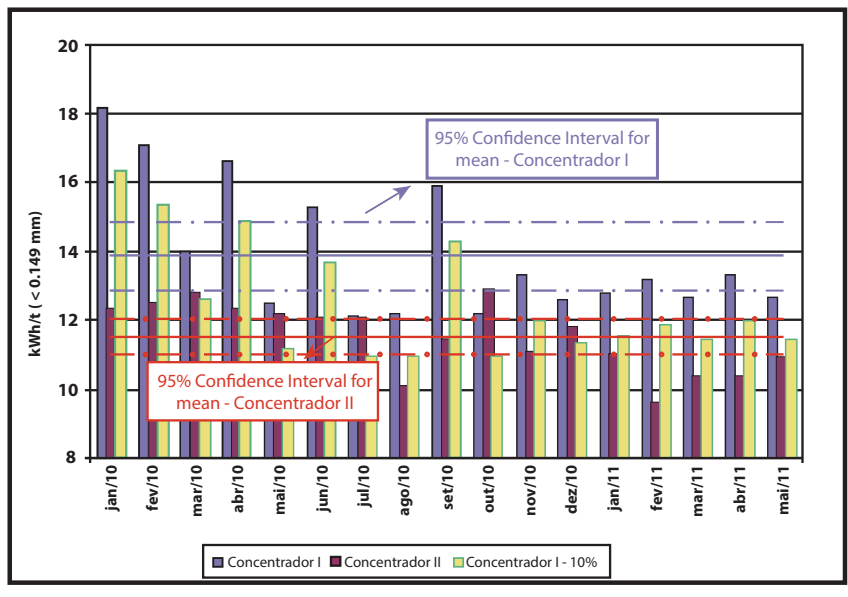

The grinding circuit of Concentrator I consists of two stages, the first operating in the open circuit mode. In literature, this configuration is known to be less energy efficient. At Samarco, it is common practice to apply the correction factor proposed by Rowland for open circuits before using the data from the first stage. However, even after the application of this factor, the specific energy consumption in Concentrator I is higher than that in Concentrator II, as shown in Figure 5.

To supplement this analysis, lab grinding tests were employed, with the following results:

- The standard sample had $49.5 \%$ passing in $0.149 \mathrm{~mm}$; the oversize fraction of this same sample, after screening in a $0.210-\mathrm{mm}$ sieve, had $4.7 \%$ passing in $0.149 \mathrm{~mm}$, while the undersize fraction had $89.1 \%$ passing.

- The standard sample had $57.4 \%$ passing in $0.210 \mathrm{~mm}$.

- The energy consumption required to grind the standard sample to $89 \%$ passing in $0.149 \mathrm{~mm}$, (just as the undersize of the screened sample) is 4.4 $\mathrm{kWh} / \mathrm{t}$. of previous analyses. However, the parameter $\mathrm{kWh} /-100 \#$ did not show any correlation between the two circuits, as shown in Figure 4.
Figure 4

"kWh/t<100\#" for the reverse and direct circuits.

circuit of Concentrator I (which operates in the reverse circuit configuration).

Figure 5

Comparison of historical industrial data between Concentrators I and II.

- The energy consumption required to grind the oversize of the screened sample to $89 \%$ passing in $0.149 \mathrm{~mm}$ is 8.1 $\mathrm{kWh} / \mathrm{t}$.

However, for the reverse circuit, a fraction of the new feed is not sent to the mill, i.e., it does not consume grinding energy. If it is assumed that an "ideal" classification takes place before the mill stage or that all particles smaller than $0.210 \mathrm{~mm}$ reported to the fine fraction, it can be presumed that the fraction of the new feed that would be fed into the mill would be

$$
\% \text { mass }=100-57.4=42.6 \%
$$

Considering that only this mass fraction would consume grinding energy, the energy consumption of the reverse circuit would be

$$
E=0.426 \times 8.1=3.45 \mathrm{kWh} / \mathrm{t}
$$


In this case, the reverse circuit would present a specific energy consumption $27 \%$ smaller than that of the direct circuit.

However, lab sieving procedures usually results in higher separation efficiency than an industrial classifying operation, especially when hydrocyclones are employed. The oversize fraction of the screened sample presented only $4.7 \%$ of fines. If hydrocyclones were used, the

Table 1

Parameters used to calibrate Nageswararao's model.

The simulation results demonstrated the following:

- The hydrocyclone underflow exhibited $32 \%$ passing in $0.149 \mathrm{~mm}$, which is a much higher percentage than

Therefore, the reverse circuit would not provide any energy savings compared with the direct circuit (which presented an energy consumption of $4.4 \mathrm{kWh} / \mathrm{t}$ ).

This exercise shows that the benefits of removing natural fines from the mill feed are dependent on the classification stage performance. Hydrocyclones are usually used in industrial grinding circuits, and, although they present various advantages, such as high throughput and easy installation, they usually have smaller separation efficiencies than screens.

Regardless the high amount of natural fines in the Samarco run of mine, the original grinding circuit was designed with a direct configuration. The follow-

\section{Conclusions}

In the sampling campaigns conducted in this study, the results for the reverse and direct grinding circuits did not differ significantly. However, the historical data from Germano Concentrators I and II demonstrate that the direct circuit, which is used in Concentrator II, exhibited a smaller amount of fines expected on the coarse product would be much higher, which would reduce the energy benefits attributed to the reversed circuit.

To illustrate this fact, a computer simulation was performed to estimate the size distribution for both the underflow and overflow of a classification made in hydrocyclones for the same sample used in the grinding tests.
Both the hydrocyclone dimensions and the operational parameters used to calibrate the model were obtained from the industrial grinding circuit of Concentrator II. The objective was to reproduce in the hydrocyclone overflow the same percentage passing in $0.149 \mathrm{~mm}$ of the undersize fraction of the screened sample. Table 1 shows the parameters used to calibrate the model.

\begin{tabular}{l|l}
\hline Hydrocyclone diameter & $26^{\prime \prime}(660 \mathrm{~mm})$ \\
\hline Vortex diameter & $12^{\prime \prime}(305 \mathrm{~mm})$ \\
\hline Apex diameter & $5^{\prime \prime}(127 \mathrm{~mm})$ \\
\hline Diameter of circle with the same area as the inlet & $192 \mathrm{~mm}$ \\
\hline Length of cylindrical section & $500 \mathrm{~mm}$ \\
\hline Cone full angle & $20^{\circ}$ \\
\hline Feed pressure & $82 \mathrm{kPa}$ \\
\hline Feed percentage of solids & $65 \%$ \\
\hline
\end{tabular}

the amount of fines observed in the oversize fraction of the sample screened in the laboratory.

- Mass recovery to the underflow product was $69 \%$, which means that $69 \%$

$$
E=0.69 \mathrm{x} 8.0=5.6 \mathrm{kWh} / \mathrm{t}
$$

ing practical operational issues justify this choice:

- Easy flowsheet: keeping the circuit simple is the key to guaranteeing projected results. For primary grinding circuits, slurring operations are complicated and consist of a limiting factor for the application of a reverse circuit. Therefore, it is necessary to evaluate whether eventual process gains would be annulled by the difficulties imposed by the proposed solution regarding the operation of the circuit.

- Grinding effects on the following operations: many studies, as the presented by Edwards and Dick (2004), Kimplel (1996), Ahmed (2010), Banisi et. al. of new feed would be reported to the mill. By following the same exercise performed before for the grinding tests, the energy requirement for the reverse circuit can be estimated as

(2002) and Bazin, Houdouin and Cooper (2001), alert to the effects of grinding product characteristics on subsequent operations, especially the concentration ones. At Samarco, Santos and Donda (2001) studied the inclusion of a classification stage before primary grinding in Concentrator I. Although Santos and Donda achieved higher recovery indexes with the desliming circuit, the losses on flotation were significant. The surface preparation provided by grinding on natural fines was clearly essential for reagent selectivity.

Therefore, there are no general rules that can be applied to the choice of a grinding circuit. specific energy consumption than the reverse circuit used in Concentrator I.

This difference was attributed to the separation efficiency of the classification stage, which was considered a determining factor on the grinding circuit performance.

Additional simulations demon- strated that the classification stage efficiency could alter or even negate the benefits of the reverse circuit.

In addition to the effects of the classifications stage, the operational aspect should be considered when choosing a grinding circuit configuration. 


\section{References}

AHMED, M.M. Effect of comminution on particle shape and surface roughness and their relation to flotation process. International Journal of Mineral Processing, n. 94, p. 180-191, 2010.

BANISI, S. et al. Effect of ball size change on the performance of grinding and flotation circuits of the Sarcheshmeh copper mine. In: ANNUAL MEETING OF THE CANADIAN MINERAL PROCESSORS, 34. Ottawa, 2002.

BAZIN, C., HODOUIN, D., COOPER, M. Interactions between grinding and flotation. In: Interactions in Mineral Processing. COM, 2001. p. 3-16.

BOND, F.C. Confirmation of the third theory. AIME Transactions. San Francisco, 1960.

BOND, F.C. Crushing and grinding calculations. Allis-Chalmers Publication, 1961.

DONDA, J.D. Um método para prever o consumo específico de energia na (re)moagem de concentrados de minérios de ferro em moinhos de bolas. Ph.D Thesis. Belo Horizonte: Universidade Federal de Minas Gerais, 2003 (Ph.D Thesis).

EDWARDS, C., DYCK, K. Replacement of classification screens with cyclones in the McArthur River Uranium Mine grinding circuit. In: ANNUAL MEETING OF THE CANADIAN MINERAL PROCESSORS, 36. Ottawa, 2004.

JKTECH. JKSimMet steady state mineral processing simulator - version 5.1. Indooroopilly, 2003. In:https://downloads.jktech.com.au/JKSimMetV5.2.01Release/ JKSimMet\%20V5.2.01\%20Basic\%20Install\%20Files/JKSimMet\%20V5.1\%20 Manuals/. Accessed on 14. dec. 2009.

KIMPLEL, R.R. Some industrial experiences in modifying fine grinding environments for improved downstream product performance. International Journal of Mineral Processing, n. 44, p. 133-142, 1996.

ROWLAND JR, C.A. The tools of power power: the bond work index, a tool to measure grinding efficiency. In: Selection Circuits to Prepare Beneficiation Feeds. Allis Chalmers Bulletin,1983.

SANTOS, I.J.; DONDA, J.D. Estudo da introdução de etapa de classificação na pré-moagem. Samarco Mineração Report, n. GBEN-025/01, 2001.

Received: 24 July 2013 - Accepted 23 March 2013. 